\title{
Kinetic and Prediction Modeling Studies of Organic Pollutants Removal from Municipal Wastewater using Moringa oleifera Biomass as a Coagulant
}

\author{
Bashir Adelodun 1,2 (D), Matthew Segun Ogunshina ${ }^{2}$, Fidelis Odedishemi Ajibade ${ }^{3,4}$ (D), \\ Taofeeq Sholagberu Abdulkadir ${ }^{5}$, Hashim Olalekan Bakare ${ }^{6}$ and Kyung Sook Choi ${ }^{1,7, *(D)}$ \\ 1 Department of Agricultural Civil Engineering, Kyungpook National University, Daegu 41566, Korea; \\ adelodun.b@unilorin.edu.ng \\ 2 Department of Agricultural and Biosystems Engineering, University of Ilorin, PMB 1515, Ilorin 240103, \\ Nigeria; segunogunshina@gmail.com \\ 3 Department of Civil and Environmental Engineering, Federal University of Technology, PMB 704, \\ Akure 340001, Nigeria; foajibade@futa.edu.ng \\ 4 Research Centre for Eco-Environmental Sciences, Chinese Academy of Sciences, Beijing 100085, China \\ 5 Department of Water Resources and Environmental Engineering, University of Ilorin, PMB 1515, \\ Ilorin 240103, Nigeria; abdulkadir.ts@unilorin.edu.ng \\ 6 Department of Chemical Engineering, University of Ilorin, PMB 1515, Ilorin 240103, Nigeria; \\ hashlek2016@gmail.com \\ 7 Institute of Agricultural Science \& Technology, Kyungpook National University, Daegu 41566, Korea \\ * Correspondence: ks.choi@knu.ac.kr; Tel.: +82-53-950-5731; Fax: +82-53-950-6752
}

Received: 13 June 2020; Accepted: 16 July 2020; Published: 19 July 2020

\begin{abstract}
This study investigated the potential of Moringa oleifera (MO) seed biomass as a coagulant for the removal of turbidity, biochemical oxygen demand (BOD), and chemical oxygen demand (COD) of municipal wastewater. Triplicated laboratory experiments using MO coagulant added at varying treatment dosages of 50,100,150, $200 \mathrm{mg} / \mathrm{L}$, and a control $(0 \mathrm{mg} / \mathrm{L})$ treatment were performed for a settling period of $250 \mathrm{~min}$ at room temperature. Kinetics and prediction variables of cumulative turbidity, BOD, and COD removal were estimated using simplified first order and modified Gompertz models. Results showed that the maximum removal of turbidity, BOD, and COD were $94.44 \%, 68.72 \%$, and $57.61 \%$, respectively, using an $\mathrm{MO}$ dose of $150 \mathrm{mg} / \mathrm{L}$. Various kinetic parameters, such as rate constant $(r)$, measured $\left(\mathrm{RE}_{\mathrm{m}}\right)$ versus predicted $\left(\mathrm{RE}_{\mathrm{p}}\right)$ cumulative removal, and specific pollutant removal rate $\left(\mu_{\mathrm{m}}\right)$, were also maximum when an $\mathrm{MO}$ dose of $150 \mathrm{mg} / \mathrm{L}$ was added, the standard error being below $5 \%$. The developed models were successfully validated over multiple observations. This study suggests low cost and sustainable removal of turbidity, BOD, and COD of municipal wastewater using $\mathrm{MO}$ seed biomass as a coagulant.
\end{abstract}

Keywords: kinetic studies; Moringa oleifera; plant seed biomass; prediction modeling; wastewater treatment

\section{Introduction}

An increasing human population and emerging lifestyles, among other factors, have greatly influenced the quality and quantity of municipal wastewater generation. The discharge of wastewater, which most times contains toxic organic and inorganic pollutants, without proper treatment into the ecosystem is widespread in developing countries and has been a great threat to human and aquatic life [1,2]. The growing concern of environmental degradation and water causing health-related issues including pollution of the water body and the scarcity of clean water has recently become the interest of researchers to achieve one of the Sustainable Development Goals (SDGs) of clean water 
and sanitation. It is estimated that about 1.1 billion people have no access to clean and safe potable water, and a significant number of them are in less developed countries of the world [3,4].

Owing to these, several techniques and processes have been developed and explored in the treatment of wastewater, among which are precipitation, ion exchange, filtration, electrodialysis, electrochemical process, coagulation, membrane process, and reverse osmosis [5]. However, the applicability of these technologies and techniques are limited in the developing world due to the cost and technical know-how constraints in the procurement of the raw materials and treatment processes required for these techniques [4-6]. Moreover, some of these treatment methods use excessive chemicals, generate secondary wastes which are often difficult to treat, and are found to be inefficient in the treatment of municipal wastewater due to the fact of varying forms of pollutants [7-9].

Recently, there has been a tremendous campaign on the use of sustainable approaches to address the environmental challenges of wastewater treatment and remediation [9-11]. In this regard, bio-coagulants such as Moringa oleifera (MO) biomass seeds have been recommended and extensively used as an effective alternative for the treatment of wastewaters, notably in Africa and Asia [2,12]. The MO biomass seeds, specifically, have gained remarkable attention in the research community due to its applicability as a coagulant and an antimicrobial agent in water and wastewater treatment $[4,13]$. The MO biomass offers a promising solution to wastewater treatment with less cost, availability of the raw materials, and higher efficiency in the removal of contaminants. In addition, the byproducts are ecofriendly as compared to other treatment processes or techniques including biological treatment methods $[12,14]$.

The wastewater treatment using MO biomass is based on the coagulation-flocculation process in which the pollutant removal is achieved due to the presence of cationic protein in MO biomass seed $[15,16]$, thereby forming small flocs with suspended particles and organic matters in the wastewater which are allowed to settle or sediment under varying contact times $[10,17]$. The coagulation mechanism of an MO biomass seed has been well discussed in the literature. Ndabigengesere et al. [17] described the coagulation mechanism of the $\mathrm{MO}$ biomass coagulant as adsorption and neutralization of charges, while Muyibi and Evison [18] attributed it to the bridging of destabilized particles. Okuda et al. [19] on the other hand, associated the variations in the coagulation mechanism of MO biomass coagulant in pollutant removal to the type of extractant used for the active component of the coagulant. Hoa and Hue [10] referred to the adsorption process as one of the main mechanisms of the coagulation process used by $\mathrm{MO}$ biomass. Despite the significant contributions on the coagulation mechanism of the MO biomass coagulant, the mechanism of pollutant removal by MO biomass through the settling ability of the flocs is not well discussed. Viotti et al. [20,21] re-emphasized the need for further studies on the removal of organic pollutants using the MO biomass. The inadequate details in this area create an important knowledge gap that needs to be considered. Appropriate models that describe the pollutant removal process could be valuable tools in this regard [22,23]. The studies that model the kinetic removal of pollutants in municipal wastewater using MO biomass as a coagulant are few, and to the best of our knowledge, there are no available publications on the applicability of a modified Gompertz model for the prediction of pollutant removal using MO biomass. The kinetic study offers valuable information on the mechanism of the reaction and pollutant removal process [14,24]. Also, MO biomass offers a cost-effective, easily accessible, and efficient pollutant removal from water and wastewater system as compared to other regular coagulants, such as alum and ferric chloride, making it a sustainable alternative to the developing countries $[4,16]$.

Therefore, this study investigated the kinetic study of pollutants removal from municipal wastewater to further understand the $\mathrm{MO}$ biomass removal mechanism. The simplified form of the first-order kinetic model was applied to describe the pollutant removal process and the model parameters were subsequently estimated. The predictions of removal pollutants for turbidity, BOD, and COD were further conducted using the modified Gompertz model. 


\section{Materials and Methods}

\subsection{MO Biomass and Sample Preparation}

The MO seed pods were collected from the Kwara State Ministry of Agriculture, Ilorin, Nigeria. The seeds were allowed to mature in the pod while still on the tree before plucking. This procedure was to ensure that the bioactive coagulants in the seed were effective [17]. The preparation of MO seeds involved two processes; the shelling of $\mathrm{MO}$ seeds from the dry pods, and the extraction of oil from the seeds to obtain MO powder as described by Farzadkia et al. [22] and Muyibi et al. [25], respectively. The MO pods were manually shelled using a knife to obtain the seeds after which the seeds were air-dried to maintain its uniform weight. The MO dried seeds were powdered using an electric grinder (Eurosonic Model ES-242) and sieved through a $0.5 \mathrm{~mm}$ mesh screen size to obtain MO biomass with uniform particle size.

Sixty grams of $\mathrm{MO}$ powder, mixed with $170 \mathrm{~mL}$ of hexane solvent, was fed into electro-thermal soxhlet extractor at $70{ }^{\circ} \mathrm{C}$ to extract the oil. The oil extraction process lasted for $4 \mathrm{~h}$ after which the solvent was left to condense and thereby separated from the oil. The resulting residue of $\mathrm{MO}$ after the oil extraction of $35 \% \mathrm{w} / \mathrm{w}$ was oven-dried at $50{ }^{\circ} \mathrm{C}$ overnight to obtain MO cake. Muyibi et al. [25] reported the enhanced coagulating potential of $\mathrm{MO}$ seeds after oil extraction. The obtained MO cake was, therefore, used in this study.

\subsection{Sampling and Characterization of Wastewater}

The samples of wastewater were taken from the main outlet of the sewer network system of the University of Ilorin main campus, Ilorin, Nigeria. The collected wastewater samples were transported to the laboratory within the University and then characterized about $1 \mathrm{~h}$ after the collection. The sample collection and analyses were carried out following the Standard Methods for Water and Wastewater Examination [26].

\subsection{Experimental Design and Calculation of Turbidity, BOD and COD Removal Efficiency}

The sampled wastewater of $1000 \mathrm{~mL}$ each, after the initial analyses for various parameters including turbidity, BOD, and COD, was filled into the five beakers in a Jar test set-up of Janke and Kunkel (Lovibond ET 730). The prepared samples of MO coagulants were then added at varying treatment dosages of 50,100, 150, and $200 \mathrm{mg} / \mathrm{L}$, with the last beaker used as control $(0 \mathrm{mg} / \mathrm{L})$. The samples of wastewater with the MO biomass coagulant were adjusted for $\mathrm{pH}$ levels $(7.26 \pm 0.09)$ using $0.5 \mathrm{M}$ of $\mathrm{NaOH}$ or $0.5 \mathrm{M}$ of $\mathrm{HCl}$ after which the samples were mixed rapidly at $100 \mathrm{rpm}$ for $2 \mathrm{~min}$, followed by slow mixing at $40 \mathrm{rpm}$ for $20 \mathrm{~min}$ to aid sludge formation. Then the samples were gently transferred and allowed to settle in the sedimentation cones (Imhoff) at a different contact time of 50,100, 150, 200, and $250 \mathrm{~min}$. An aliquot of $250 \mathrm{~mL}$ was sampled from each sedimentation cone, and turbidity, BOD, COD were determined for each contact time, in triplicate. The removal efficiency of turbidity, BOD, and COD using varying $\mathrm{MO}$ dosage for each of the contact time was calculated using Equation (1)

$$
\text { Removal efficiency }(R E \%)=\left(\frac{C_{i}-C_{f}}{C_{i}}\right) \times 100
$$

where $C_{i}$ and $C_{f}$ are the initial and final values of the analyzed parameters, respectively, expressed in NTU for turbidity, and $\mathrm{mg} / \mathrm{L}$ for BOD and COD.

\subsection{Kinetics of Turbidity, BOD and COD Removal}

The pollutant removal rate of any wastewater treatment processes is one of the most important parameters used to define the effectiveness of reaction-based systems [23,27-29]. Therefore, the rate of solute sorption onto MO biomass was estimated. To evaluate the kinetics of turbidity, BOD, 
and COD removal process, a simplified form of the first-order kinetic model was used [28]. The form of the equation is given in Equation (2).

$$
r=\log \left(\frac{\mathrm{C}_{\mathrm{i}}}{\mathrm{C}_{\mathrm{t}}}\right) \cdot \frac{2.303}{\mathrm{t}_{2}-\mathrm{t}_{1}}
$$

where $r$ represents the rate constant of pollutant removal reaction (NTU $\min ^{-1}$ and $\mathrm{mg} / \mathrm{L} \mathrm{min}^{-1}$ ), while $C_{i}$ and $C_{t}$ are the initial and final parameter at the sampling interval $\left(t_{2}-t_{1} \min \right)$.

\subsection{Modified Gompertz Model for Prediction of Turbidity, BOD and COD Removal}

Recent studies have confirmed that the application of the Gompertz equation can be used for modeling the processes having a non-linear or exponential trend [29]. In this study, the cumulative removal of turbidity, $\mathrm{BOD}$, and $\mathrm{COD}$ as a dependent variable to predict over settling time as an independent variable was considered. The cumulative parameter removal efficiency was calculated using Equation (3).

$$
\mathrm{RE}_{\mathrm{m}}=\sum_{x=1}^{n} \mathrm{RE}
$$

where $\mathrm{RE}_{\mathrm{m}}$ is the cumulative parameter removal efficiency (measured) in terms of the sum of $n$ number of observations per timespan.

This model is a modified form of a modified Gompertz model which can be expressed as:

$$
\mathrm{RE}_{\mathrm{p}}=P_{\exp }\left\{-\exp \left[\frac{\mu_{\mathrm{m}}}{P}(\lambda-\mathrm{t})+1\right]\right\}
$$

where $\mathrm{RE}_{\mathrm{p}}$ is the cumulative pollutant removal (predicted), $P$ is the maximum pollutant removal potential, $\mu_{\mathrm{m}}$ is the maximum specific pollutant removal (\%), $\lambda$ and $\mathrm{t}$ are the lag phase and settling time (min), respectively.

\subsection{Statistics}

All the experiments were performed in the triplicated form. The analysis of variance (ANOVA) test was conducted with least significance difference (LSD) for the mean difference before and after treatment for the selected parameters. Data were processed using OriginPro Version 9 (Origin Corp., Northampton, MA, USA), IBM SPSS Version 23.0 (IBM Corp., Chicago, IL, USA). A model fitting tool, namely, Rank Models of OriginPro was used to simulate the prediction models. Finally, the model data were validated over multiple experimental trials.

\section{Results and Discussion}

\subsection{Characteristics of Municipal Wastewater Used in This Study}

The characteristics of municipal wastewater before and after treatment with MO biomass coagulants are presented in Table 1 . The variables measured include $\mathrm{pH}$, TSS, electrical conductivity, turbidity, BOD, COD, alkalinity, and total hardness, and each of which was found to be statistically significant after treatment with a varying dosage of $\mathrm{MO}(50,100,150,200 \mathrm{mg} / \mathrm{L})$ as indicated in their respective $p$-value $(p<0.05)$ in Table 1 . In general, the sample wastewater before treatment was found to be neutral $(7.26 \pm 0.09)$ because of the anthropogenic activities in the University environment where the wastewater emanated. Nevertheless, the observed $\mathrm{pH}$ values, before and after treatment, were within the permissible limit for wastewater reuse in agriculture [30] and the national acceptable wastewater discharge range of $6-9$ [31]. The cumulative variance $(\mathrm{CV} \%)$ of wastewater parameters defined the less variation suitable for model building. 
Table 1. Characteristics of municipal wastewater used for this study.

\begin{tabular}{|c|c|c|c|c|c|c|c|}
\hline Parameter & MO Treatment & Before Treatment & CV $(\%)$ & After Treatment & $\begin{array}{c}\text { USEPA Permissible Limit for } \\
\text { Wastewater Reuse in Agriculture }\end{array}$ & $\begin{array}{l}\text { NESREA Permissible Limit for } \\
\text { Wastewater Discharge }\end{array}$ & Unit \\
\hline \multirow{5}{*}{$\mathrm{pH}$} & Control & \multirow{5}{*}{$7.26 \pm 0.09$} & 0.01 & $7.37 \pm 0.03 * *$ & \multirow{5}{*}{$6-8.4$} & \multirow{5}{*}{$6-9$} & \multirow{5}{*}{-} \\
\hline & $50 \mathrm{mg} / \mathrm{L}$ & & & $6.93 \pm 0.05 * * *$ & & & \\
\hline & $100 \mathrm{mg} / \mathrm{L}$ & & & $6.88 \pm 0.05^{* * *}$ & & & \\
\hline & $150 \mathrm{mg} / \mathrm{L}$ & & & $7.02 \pm 0.05^{* * *}$ & & & \\
\hline & $200 \mathrm{mg} / \mathrm{L}$ & & & $7.01 \pm 0.05 * * *$ & & & \\
\hline \multirow{5}{*}{ Total suspended solids (TSS) } & Control & \multirow{5}{*}{$111.93 \pm 15.23$} & 13.50 & $91.88 \pm 4.25 * * *$ & \multirow{5}{*}{5} & \multirow{5}{*}{25} & \multirow{5}{*}{$\mathrm{mg} / \mathrm{L}$} \\
\hline & $50 \mathrm{mg} / \mathrm{L}$ & & & $70.43 \pm 2.05 * * *$ & & & \\
\hline & $100 \mathrm{mg} / \mathrm{L}$ & & & $62.13 \pm 2.36^{* * *}$ & & & \\
\hline & $150 \mathrm{mg} / \mathrm{L}$ & & & $41.70 \pm 2.15 * * *$ & & & \\
\hline & $200 \mathrm{mg} / \mathrm{L}$ & & & $41.71 \pm 2.00 * * *$ & & & \\
\hline \multirow{5}{*}{ Turbidity } & Control & \multirow{5}{*}{$76.74 \pm 3.69$} & 4.80 & $10.88 \pm 2.00 * * *$ & \multirow{5}{*}{2} & \multirow{5}{*}{5} & \multirow{5}{*}{ NTU } \\
\hline & $50 \mathrm{mg} / \mathrm{L}$ & & & $6.52 \pm 1.15^{* * *}$ & & & \\
\hline & $100 \mathrm{mg} / \mathrm{L}$ & & & $5.35 \pm 1.15 * * *$ & & & \\
\hline & $150 \mathrm{mg} / \mathrm{L}$ & & & $4.27 \pm 1.05^{* * *}$ & & & \\
\hline & $200 \mathrm{mg} / \mathrm{L}$ & & & $4.28 \pm 1.25 * * *$ & & & \\
\hline \multirow{5}{*}{ Biochemical oxygen demand (BOD) } & Control & \multirow{5}{*}{$147.45 \pm 12.87$} & 8.72 & $144.40 \pm 4.28 \mathrm{~ns}$ & \multirow{5}{*}{30} & \multirow{5}{*}{30} & \multirow{5}{*}{$\mathrm{mg} / \mathrm{L}$} \\
\hline & $50 \mathrm{mg} / \mathrm{L}$ & & & $76.28 \pm 2.75 * * *$ & & & \\
\hline & $100 \mathrm{mg} / \mathrm{L}$ & & & $55.83 \pm 2.55 * * *$ & & & \\
\hline & $150 \mathrm{mg} / \mathrm{L}$ & & & $46.12 \pm 2.05 * * *$ & & & \\
\hline & $200 \mathrm{mg} / \mathrm{L}$ & & & $46.22 \pm 3.16^{* * *}$ & & & \\
\hline \multirow{5}{*}{ Chemical oxygen demand (COD) } & Control & \multirow{5}{*}{$474.18 \pm 10.09$} & 2.12 & $448.18 \pm 3.45^{* *}$ & \multirow{5}{*}{120} & \multirow{5}{*}{60} & \multirow{5}{*}{$\mathrm{mg} / \mathrm{L}$} \\
\hline & $50 \mathrm{mg} / \mathrm{L}$ & & & $237.28 \pm 3.00 * * *$ & & & \\
\hline & $100 \mathrm{mg} / \mathrm{L}$ & & & $204.30 \pm 1.50 * * *$ & & & \\
\hline & $150 \mathrm{mg} / \mathrm{L}$ & & & $200.88 \pm 2.52 * * *$ & & & \\
\hline & $200 \mathrm{mg} / \mathrm{L}$ & & & $201.00 \pm 2.50 * * *$ & & & \\
\hline & Control & & 0.31 & $401.01 \pm 0.03^{\mathrm{ns}}$ & & & \\
\hline & $50 \mathrm{mg} / \mathrm{L}$ & & & $429.09 \pm 0.05 * * *$ & & & \\
\hline Electrical conductance $(\mathrm{EC})$ & $100 \mathrm{mg} / \mathrm{L}$ & $402.44 \pm 1.27$ & & $438.41 \pm 0.05 * * *$ & 700 & 400 & $\mu \mathrm{S} / \mathrm{cm}$ \\
\hline & $150 \mathrm{mg} / \mathrm{L}$ & & & $447.55 \pm 0.01 * * *$ & & & \\
\hline & $200 \mathrm{mg} / \mathrm{L}$ & & & $447.76 \pm 0.05 * * *$ & & & \\
\hline & Control & & 0.48 & $383 \pm 1.26^{\text {ns }}$ & & & \\
\hline & $50 \mathrm{mg} / \mathrm{L}$ & & & $311.85 \pm 0.95 * * *$ & & & \\
\hline Alkalinity & $100 \mathrm{mg} / \mathrm{L}$ & $385.00 \pm 1.85$ & & $327.25 \pm 0.09 * * *$ & 50-150 & - & $\mathrm{mg} / \mathrm{L}$ \\
\hline & $150 \mathrm{mg} / \mathrm{L}$ & & & $329.95 \pm 1.06 * * *$ & & & \\
\hline & $200 \mathrm{mg} / \mathrm{L}$ & & & $330.05 \pm 0.28 * * *$ & & & \\
\hline & Control & & 3.38 & $125.25 \pm 1.25^{\mathrm{ns}}$ & & & \\
\hline & $50 \mathrm{mg} / \mathrm{L}$ & & & $111.36 \pm 0.12 * * *$ & & & \\
\hline Total hardness (TH) & $100 \mathrm{mg} / \mathrm{L}$ & $128.50 \pm 4.36$ & & $104.96 \pm 1.00 * * *$ & - & - & $\mathrm{mg} / \mathrm{L}$ \\
\hline & $150 \mathrm{mg} / \mathrm{L}$ & & & $101.12 \pm 1.05 * * *$ & & & \\
\hline & $200 \mathrm{mg} / \mathrm{L}$ & & & $98.56 \pm 1.28 * * *$ & & & \\
\hline
\end{tabular}

Environmental Protection Agency; NESREA is National Environmental Standards and Regulations Enforcement Agency (Establishment) Act. 
The turbidity and TSS measure the suspended particulate matters in the wastewater and can also describe the extent of wastewater pollution. Before the treatment, TSS and turbidity parameters (111.93 \pm 15.23 and $76.74 \pm 3.69)$ exceeded allowable national standard limits of $25 \mathrm{mg} / \mathrm{L}$ and $5 \mathrm{NTU}$ [32], respectively, for wastewater discharge. However, after treatment with MO biomass coagulant, the TSS value was significantly reduced while the turbidity fell within the acceptable national limit of wastewater discharge. The initial high turbidity and TSS levels could be attributed to the presence of inorganic particulate matter in the wastewater.

The initial BOD and COD values before treatment with MO biomass (147.45 \pm 12.87 and $474.18 \pm 10.09 \mathrm{mg} / \mathrm{L}$, respectively) were remarkably higher than the permissible discharge levels in Africa and Asia [32]. Although the values of both BOD and COD after treatment with $200 \mathrm{mg} / \mathrm{L}$ of MO dosage (46.22 \pm 3.16 and $201.00 \pm 2.50)$ were above the permissible limit for wastewater reuse in agriculture [30] and wastewater discharge [31]. However, there was a statistically significant difference $(p<0.001)$ between before treatment and after treatment with MO dosage. The BOD and COD indicate the extent of organic pollution in the wastewater and the high levels of these pollutants could be detrimental to the plant, animal, and human health when discharged into the environment, especially without proper treatment.

Similarly, the electrical conductivity of the wastewater, both before and after treatment, was found to be within the permissible limit of USEPA guidelines [30], and there was a significant difference between the before treatment and after treatment with $\mathrm{MO}$ biomass. Other measured parameters including alkalinity and total hardness exceeded the national standard value range of $50-100 \mathrm{mg} / \mathrm{L}$ for alkalinity whereas the standard limit for the hardness is yet to be established, revealing an indication of polluted wastewater. The three parameters, turbidity, BOD, and COD that represent both the particulate and organic pollution of the wastewater were therefore used to investigate the kinetics of the pollutant removal process.

\subsection{Effect of $M O$ Dose on Turbidity, BOD and COD Removal}

The effect of MO biomass on turbidity, BOD, and COD removal is shown in Figure 1. The removal of all the three investigated pollutants increased with the increase in the MO biomass dosages under $250 \mathrm{~min}$ settling time. The result depicts that turbidity removal reached a maximum of $94.44 \%$ with the MO biomass dosage of $150 \mathrm{mg} / \mathrm{L}$, which slightly decreased to $94.42 \%$ by increasing the dosage to $200 \mathrm{mg} / \mathrm{L}$. Therefore, there was no significant difference for turbidity removal between 150 and $200 \mathrm{mg} / \mathrm{L}$ of MO.

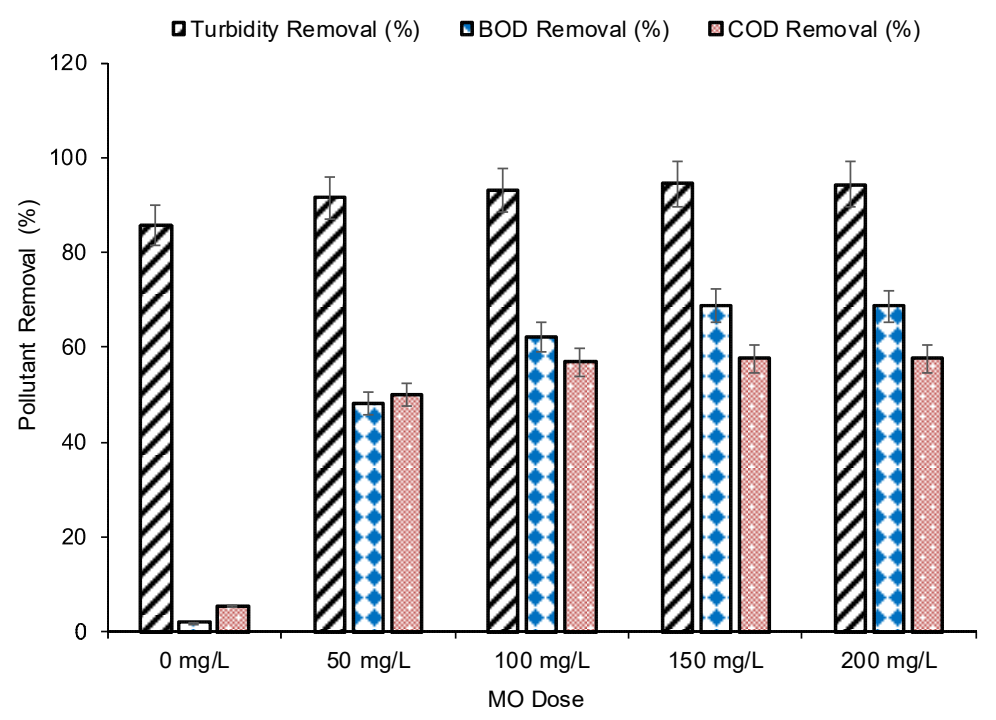

Figure 1. Effect of $\mathrm{MO}$ biomass coagulant dosage on turbidity, BOD, COD removal of municipal wastewater. 
These results are similar to those obtained by Kayode et al. [32], Kane et al. [33], and Boulaadjoul et al. [34] for municipal wastewater and paper mill effluent, respectively. Dotto et al. [35] also confirmed an improved COD removal with increasing settling time using MO coagulant in textile wastewater. The further decrease in turbidity removal could be explained by the absence of opposite charged colloidal particles needed by the excess MO biomass to react with, which have been exhaustively neutralized and precipitated with the optimum biomass dosage. The maximum BOD and COD removal of $68.72 \%$ and $57.64 \%$, respectively, was achieved at $150 \mathrm{mg} / \mathrm{L}$ of $\mathrm{MO}$ biomass dosage. The removal of the two pollutants is associated with the reduction of turbidity and organic suspended materials in wastewater [10] and as a result, the removal of both BOD and COD followed the same trend as that of turbidity removal. These results are in agreement with those obtained by Al-gheethi et al. [36] and Rosmawanie et al. [37].

\subsection{Kinetics of Turbidity, BOD, and COD Removal}

In this regard, the kinetics study of turbidity, BOD, and COD removal from municipal wastewater using MO biomass exhibited that the pollutant removal process in this study followed the reaction trend of the first-order kinetic model. The results of the first-order model for removal of turbidity, COD, and BOD are presented in Table 2.

Table 2. First-order kinetic variables for percent turbidity, BOD, and COD removal.

\begin{tabular}{|c|c|c|c|c|c|c|}
\hline \multirow{2}{*}{ Parameter } & \multirow{2}{*}{ Model Variable } & \multicolumn{5}{|c|}{ MO Treatment Dose } \\
\hline & & Control & $50 \mathrm{mg} / \mathrm{L}$ & $100 \mathrm{mg} / \mathrm{L}$ & $150 \mathrm{mg} / \mathrm{L}$ & $200 \mathrm{mg} / \mathrm{L}$ \\
\hline \multirow{3}{*}{ Turbidity } & $R^{2}$ & 0.8432 & 0.8534 & 0.8386 & 0.8335 & 0.8399 \\
\hline & $r$ & 2.2216 & 2.8276 & 3.1608 & 3.6531 & 3.6472 \\
\hline & $\mathrm{y}$ & $-0.0042 x+1.8143$ & $-0.0051 x+1.8256$ & $-0.0056 x+1.82$ & $-0.0062 x+1.8265$ & $-0.0062 x+1.8266$ \\
\hline \multirow{3}{*}{ BOD } & $R^{2}$ & 0.8064 & 0.9774 & 0.9623 & 0.9638 & 0.9697 \\
\hline & $r$ & 1.0664 & 1.2234 & 1.3184 & 1.3841 & 1.3833 \\
\hline & $\mathrm{y}$ & $-0.0005 x+2.1667$ & $-0.0012 x+2.1557$ & $-0.0018 x+2.1478$ & $-0.0022 x+2.146$ & $-0.0022 x+2.1462$ \\
\hline \multirow{3}{*}{$\mathrm{COD}$} & $R^{2}$ & 0.9912 & 0.8755 & 0.8534 & 0.8675 & 0.8696 \\
\hline & $r$ & 0.8686 & 0.9696 & 0.9969 & 0.9999 & 0.9999 \\
\hline & $\mathrm{y}$ & $-0.0001 x+2.6760$ & $-0.0013 x+2.6357$ & $-0.0016 x+2.6262$ & $-0.0016 x+2.6269$ & $-0.0016 x+2.6261$ \\
\hline
\end{tabular}

$R^{2}$ : coefficient of determination; $r$ : first-order rate constant; $\mathrm{y}$ : linear fitness equation of $\log (\mathrm{C})$ versus time $\mathrm{t}(x)$.

The data were best fitted in Equation (2) and gave satisfactory results for the applicability of the model in turbidity, BOD, and COD removal. The plot of logarithms of turbidity, BOD, and COD versus settling time $(t)$ showed the good fitness of data points derived from experimental observations (Figure 2). It was evidenced that the coefficient of determination $\left(R^{2}\right)$ values for time course turbidity, BOD, and COD removal ranged from 0.8335-0.8534, 0.8064-0.9774, and 0.8686-0.9999, respectively. Besides this, the rate constant $(r)$ was encountered in control treatment for turbidity $\left(2.2216 \mathrm{NTU} \mathrm{\textrm {min } ^ { - 1 }}\right)$, BOD $\left(1.0664 \mathrm{mg} / \mathrm{L} \cdot \mathrm{min}^{-1}\right)$, and COD $\left(0.8686 \mathrm{mg} / \mathrm{L} \cdot \mathrm{min}^{-1}\right)$ removal, correspondingly (Figure 3$)$. Though, there was a variation in the $k$ values of $150 \mathrm{mg} / \mathrm{L}$ and $200 \mathrm{mg} / \mathrm{L} \mathrm{MO}$ treatments. However, the overall maximum removal of turbidity, BOD, and COD in a total of $250 \mathrm{~min}$ of settling allowance was achieved in $150 \mathrm{mg} / \mathrm{L}$ of MO dose along with a reasonable $k$ value.

The pollutant removal rate in a reaction-based system depends on numerous internal and external factors such as temperature, dose, and particle of plant biomass, agitation, aeration, retention period, and characteristics of wastewater itself [38]. The plant biomass has both physical and chemical binding sites that capture the pollutant particles and forms a complex. As the reaction initiates, the pollutant particle starts attaching to these sites, and the net weight of plant biomass particles is increased [39]. The reaction lasts until the complete saturation of the free sites, and finally, the rapid settling of the particle occurs. The reaction is largely dependent on solute and solvent properties which determines the net pollutant removal efficiency of such systems. Previously, Viotti et al. [20] investigated the adsorption kinetic removal of diclofenac from wastewater using MO biomass. Their results indicated an adsorption capacity of $60.805 \mathrm{mg} / \mathrm{g}$ for MO biomass with a significant efficiency as compared to the activated carbon with a maximum adsorption capacity of $71.150 \mathrm{mg} / \mathrm{g}$. 
Adsorption of nonylphenol in wastewater using kinetics study was also investigated by Dai et al. [40], and the adsorption process fitted well into the Elovich kinetics. Similarly, Sacher et al. [41] compared three classical kinetic models including zero-, first-, and second-order kinetics to determine the removal of monochloride in Loire river water. The only first-order model fitted well into their kinetic data under the applied experimental conditions, while other forms of kinetic models showed significant random variations. Chen et al. [42] studied the kinetics of zinc removal from wastewater using the first-order model. They confirmed that zinc removal was significantly affected by the initial dose of zinc ions during the electrocoagulation process. Similarly, Kumar et al. [28] conducted lab-scale experiments of phyto-treatment of sugar mill effluent using water hyacinth plants in the CSTR system assisted with direct current (DC). They analyzed the kinetics of BOD and COD reduction in the CSTR system and found the maximum BOD and COD rates of $0.54 \mathrm{mg} / \mathrm{L} \mathrm{week}^{-1}$ and $0.90 \mathrm{mg} / \mathrm{L} \mathrm{week}^{-1}$, respectively, using the first-order model.

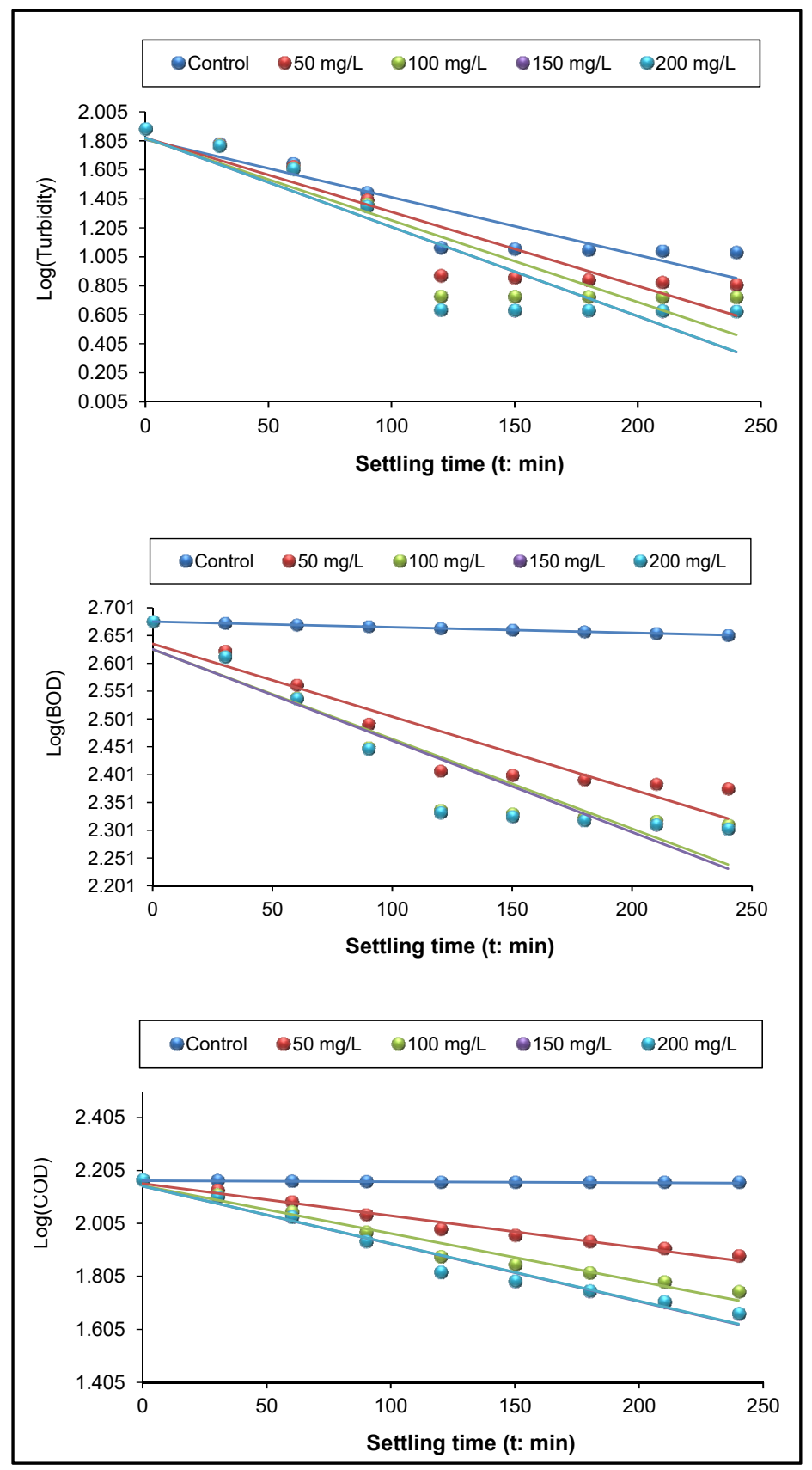

Figure 2. $\log (\mathrm{C})$ versus time (t: $\mathrm{min})$ plots of turbidity, BOD, COD removal of municipal wastewater. 

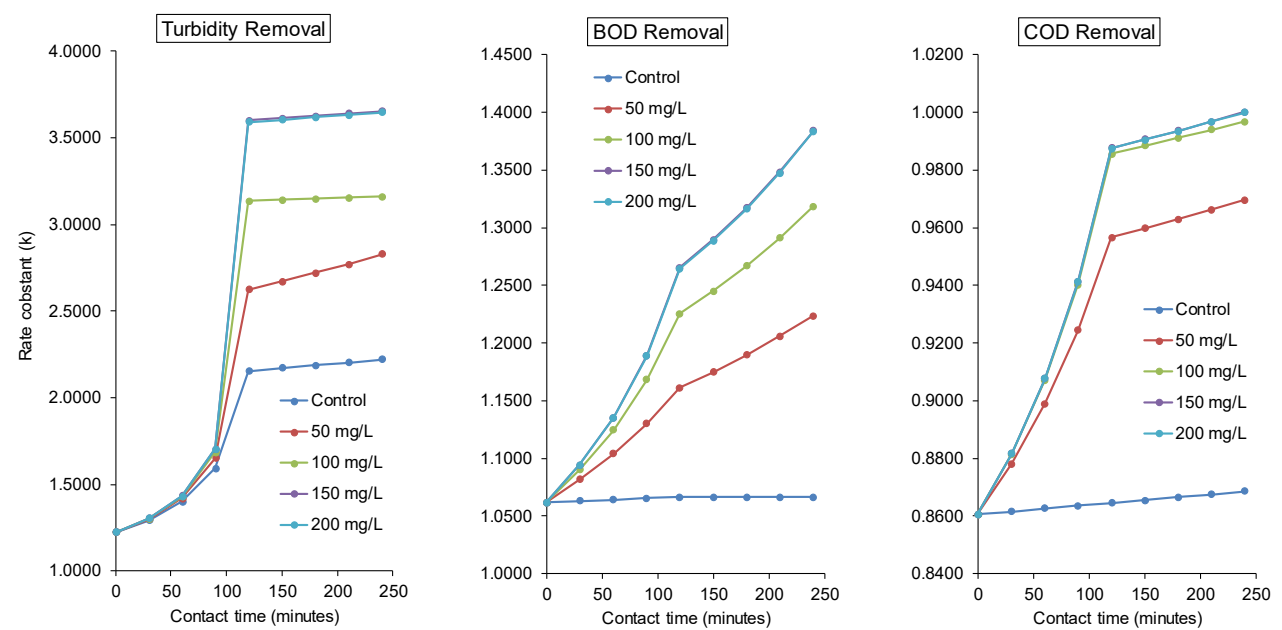

Figure 3. The first-order rate constant $(r)$ of cumulative turbidity $\left(\mathrm{NTU} \mathrm{min}^{-1}\right), \mathrm{BOD}\left(\mathrm{mg} / \mathrm{L} \cdot \mathrm{min}^{-1}\right)$, and $\operatorname{COD}\left(\mathrm{mg} / \mathrm{L} \cdot \mathrm{min}^{-1}\right)$ removal of municipal wastewater using $\mathrm{MO}$ coagulant.

\subsection{Prediction and Validation of Model Results}

Prediction modeling results of cumulative turbidity, BOD, and COD removal using the modified Gompertz kinetic model are given in Table 3. From the final results, it was evidenced that the model can be successfully implemented for simulation of turbidity, BOD, and COD removal from municipal wastewater using MO biomass. The results showed that the coefficient of determination $\left(R^{2}\right)$ had strong fitness of experimental data, which ranged from $0.98-0.99$ for cumulative turbidity, BOD, and COD removal.

Table 3. Measured versus predicted percent (\%) removal of turbidity, BOD, and COD with Gomphertz model variables.

\begin{tabular}{|c|c|c|c|c|c|c|}
\hline \multirow{2}{*}{ Parameter } & \multirow{2}{*}{ Variable } & \multicolumn{5}{|c|}{ MO Treatment Dose } \\
\hline & & Control & $50 \mathrm{mg} / \mathrm{L}$ & $100 \mathrm{mg} / \mathrm{L}$ & $150 \mathrm{mg} / \mathrm{L}$ & $200 \mathrm{mg} / \mathrm{L}$ \\
\hline \multirow{6}{*}{ Turbidity } & $R E_{m}$ & 85.82 & 91.49 & 93.02 & 94.44 & 94.42 \\
\hline & $\mathrm{RE}_{\mathrm{p}}$ & 87.50 & 93.24 & 95.22 & 96.97 & 96.95 \\
\hline & $\mathrm{S}_{\mathrm{E}}$ & 2.24 & 2.37 & 2.51 & 2.55 & 2.53 \\
\hline & $\Lambda \mathrm{m}$ & 45.94 & 45.99 & 45.56 & 45.57 & 45.58 \\
\hline & $\mu$ & 0.0291 & 0.0290 & 0.0293 & 0.0296 & 0.0294 \\
\hline & $R^{2}$ & 0.98 & 0.98 & 0.98 & 0.98 & 0.98 \\
\hline \multirow{6}{*}{ BOD } & $\mathrm{RE}_{\mathrm{m}}$ & 2.07 & 48.26 & 62.14 & 68.72 & 68.65 \\
\hline & $\mathrm{RE}_{\mathrm{p}}$ & 2.10 & 46.58 & 61.71 & 68.15 & 68.08 \\
\hline & $\mathrm{S}_{\mathrm{E}}$ & 0.05 & 1.64 & 1.57 & 1.61 & 1.62 \\
\hline & $\Lambda \mathrm{m}$ & 45.99 & 63.32 & 56.82 & 55.16 & 55.24 \\
\hline & $\mu$ & 0.0290 & 0.0177 & 0.0205 & 0.0214 & 0.0213 \\
\hline & $R^{2}$ & 0.99 & 0.99 & 0.99 & 0.99 & 0.99 \\
\hline \multirow{6}{*}{ COD } & $\mathrm{RE}_{\mathrm{m}}$ & 5.48 & 49.96 & 56.92 & 57.64 & 57.61 \\
\hline & $\mathrm{RE}_{\mathrm{p}}$ & 5.37 & 50.24 & 57.38 & 58.05 & 58.02 \\
\hline & $\mathrm{S}_{\mathrm{E}}$ & 0.74 & 1.10 & 1.34 & 1.35 & 1.34 \\
\hline & $\Lambda \mathrm{m}$ & 117.89 & 48.31 & 47.15 & 47.28 & 47.29 \\
\hline & $\mu$ & 0.0092 & 0.0265 & 0.0277 & 0.0276 & 0.0276 \\
\hline & $R^{2}$ & 0.99 & 0.99 & 0.99 & 0.99 & 0.99 \\
\hline
\end{tabular}

$\mathrm{RE}_{\mathrm{m}}$ : Measured removal (\%); $\mathrm{RE}_{\mathrm{p}}$ : predicted removal (\%) using modified Gompertz model; $\mathrm{S}_{\mathrm{E}}$ : standard error in prediction; $\lambda_{\max }$ : lag phase in min; $\mu \mathrm{m}$ : specific removal rate per min; and $R^{2}$ : coefficient of determination. 
Furthermore, the predicted removal in all MO treatments was intensely close to the measured removal. Figures 4 and 5 give graphical representations of comparison of predicted and measured turbidity, BOD, and COD removal. The maximum measured $\left(R_{m}\right)$ versus predicted $\left(R_{p}\right)$ removal of turbidity ( $\mathrm{RE}_{\mathrm{m}}$ : 94.44 and $\mathrm{RE}_{\mathrm{p}}$ : 96.97), $\mathrm{BOD}\left(\mathrm{RE}_{\mathrm{m}}: 68.72\right.$ and $\left.\mathrm{RE}_{\mathrm{p}}: 68.15\right)$, and $\mathrm{COD}\left(\mathrm{RE}_{\mathrm{m}}: 57.64\right.$ and $\mathrm{RE}_{\mathrm{p}}$ : 58.05) indicated that the models had an acceptable and small standard error in prediction $(<5 \%)$. The maximum specific removal rate $\left(\mu_{\mathrm{m}}\right)$ was maximum in $150 \mathrm{mg} / \mathrm{L} \mathrm{MO}$ treatment for all the three selected parameters. However, all the model parameters in $200 \mathrm{mg} / \mathrm{L} \mathrm{MO}$ treatment were slightly less than the parameter values of $150 \mathrm{mg} / \mathrm{L}$ MO treatment, therefore, increasing the $\mathrm{MO}$ dose after $150 \mathrm{mg} / \mathrm{L}$ was not recommended. Also, the medium values of the lag phase $\left(\lambda_{\max }\right)$ revealed that the initial settling time of $150 \mathrm{~min}$ was the most determining phase in which the maximum specific pollutant removal was achieved. However, the models were developed based on the specific municipal wastewater and the estimated variables may vary according to the water quality. Still, the methodology suggests the good fitness of the models in determining the major factors of the municipal wastewater treatment process.

In our findings, the modified Gompertz model-based variables increased from control treatment to $150 \mathrm{mg} / \mathrm{L}$ MO treatment and further decreased to $200 \mathrm{mg} / \mathrm{L}$. The stability of these model variables may be associated with the kinetic factors, i.e., solute (MO biomass) concentration. A high dose of MO may not be kinetically feasible for the pollutant capture reaction, and, therefore, the reaction rate was stabilized. The good fitness of the non-linear curve, as demonstrated in Figure 4, explained the feasibility of the modified Gompertz model in the present study. Recently, Carvajal et al. [43] studied the pollutant removal kinetics and their relative impact of anoxic BTEX biodegradation using the modified Gompertz model. They precisely modeled the BTEX biodegradation and showed that the higher concentration mixture might cause an inhibitory effect on the degradation process. Báez et al. [29] investigated the pollutant load removal efficiency of whey using a modified Gompertz model with validation of the results by specific model verification tools like $R^{2}$, efficiency, and standard error in prediction. Hernández-Martínez et al. [44] performed batch mode experiments in a bubble column reactor for pollutant load reduction petroleum hydrocarbons using microbial biomass. They also modeled the hydrocarbon biosorption process using the modified Gompertz model and explained the model predicted removal was near to the experimental removal.

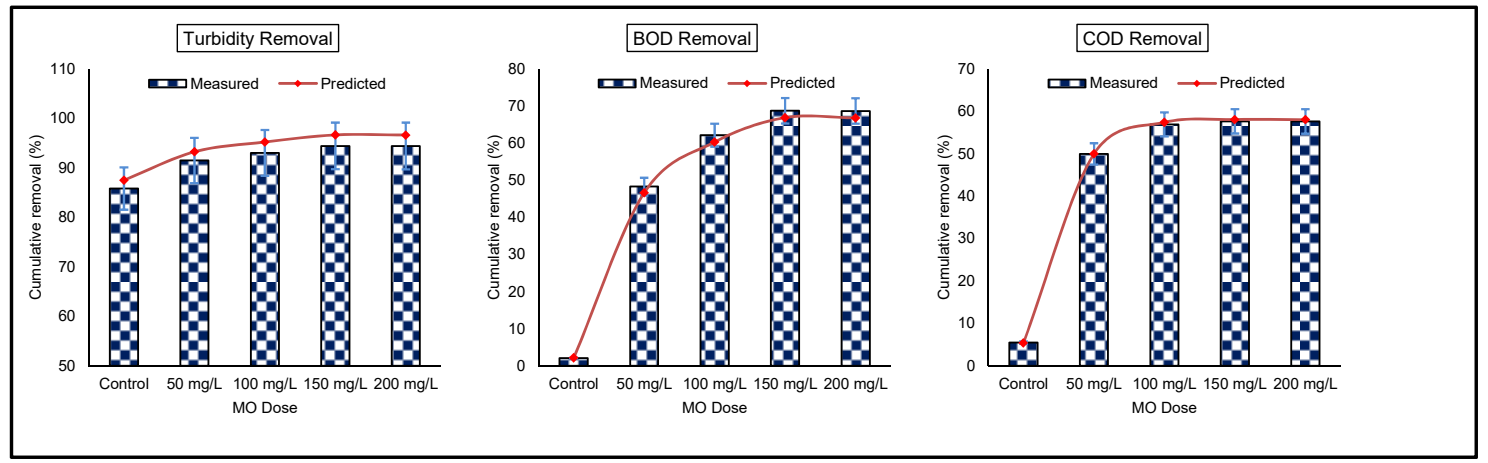

Figure 4. Effect of MO dose with measured versus predicted cumulative removal of turbidity, BOD, and COD of municipal wastewater using MO coagulant. 


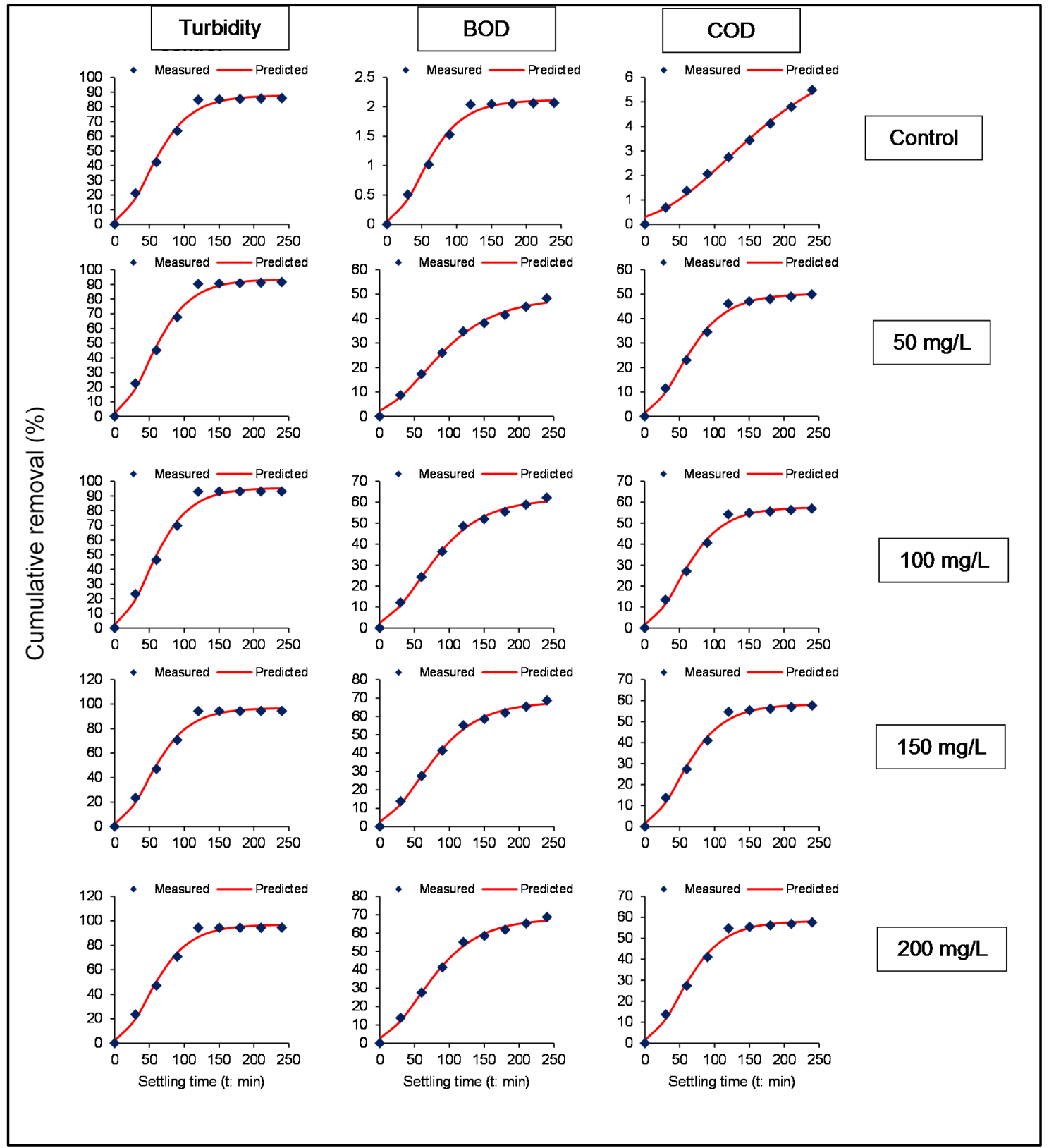

Figure 5. Experimental versus modified Gompertz model predicted cumulative removal (\%) of turbidity, BOD, COD of municipal wastewater using MO coagulant.

\section{Conclusions}

In this study, we deduced that Moringa oleifera (MO) seed biomass was an effective coagulant to reduce the pollutant load of municipal wastewater. The results revealed that a significant reduction $(p<0.05)$ of the selected wastewater parameters, viz., turbidity, BOD, and COD was achieved. Also, the kinetic modeling of the reactor system utilizing the first-order and modified Gompertz model helped to enhance the turbidity, BOD, and COD removal process. We found that among the different MO treatments $(0-200 \mathrm{mg} / \mathrm{L})$, the maximum measured $\left(\mathrm{R}_{\mathrm{m}}\right)$ and predicted $\left(R E_{\mathrm{p}}\right)$ removal of turbidity

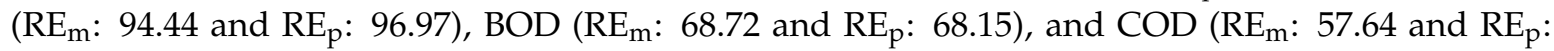
58.05) were achieved using a $\mathrm{MO}$ dose of $150 \mathrm{mg} / \mathrm{L}$ after $250 \mathrm{~min}$ of settling retention, respectively. However, the models should be tested for the treatment of other wastewaters as the variables may vary according to the water quality. The findings of this study will be essentially useful for low-cost 
primary treatment of municipal wastewater employing $\mathrm{MO}$ seed biomass and minimize its possible, disposable environmental risks.

Author Contributions: B.A. conceived the idea, conducted the experiment, analyzed the data, and wrote the manuscript. M.S.O. collected the data, performed sampling analysis, and wrote the manuscript. F.O.A. performed the data curation, analyzed the data, and revised the manuscript. T.S.A. analyzed the data and revised the manuscript. H.O.B. collected the data and revised the manuscript. K.S.C. resources and reviewed the manuscript. All authors have read and agreed to the published version of the manuscript.

Funding: This research received no external funding.

Acknowledgments: The authors would like to express their gratitude to the University of Ilorin, Ilorin for providing the necessary facilities for conducting this research. We gratefully acknowledge the assistance of Pankaj Kumar of Agro-ecology and Pollution Research Laboratory, Department of Zoology and Environmental Science, Gurukula Kangri Vishwavidyalala, Haridwar-249404 (Uttarakhand), India, who thoroughly read the manuscript and offered brilliant suggestions to improve the manuscript. In addition, the efforts of the three anonymous reviewers to further improve the manuscript are appreciated.

Conflicts of Interest: The authors declare no conflict of interest.

\section{References}

1. Freitas, J.H.E.S.; de Santana, K.V.; do Nascimento, A.C.C.; de Paiva, S.C.; de Moura, M.C.; Coelho, L.C.B.B.; de Oliveira, M.B.M.; Paiva, P.M.G.; do Nascimento, A.E.; Napoleão, T.H. Evaluation of using aluminum sulfate and water-soluble Moringa oleifera seed lectin to reduce turbidity and toxicity of polluted stream water. Chemosphere 2016, 163, 133-141. [CrossRef] [PubMed]

2. Vunain, E.; Masoamphambe, E.F.; Mpeketula, P.M.G.; Monjerezi, M.; Etale, A. Evaluation of coagulating efficiency and water borne pathogens reduction capacity of Moringa oleifera seed powder for treatment of domestic wastewater from Zomba, Malawi. J. Environ. Chem. Eng. 2019, 7, 103118. [CrossRef]

3. Abaliwano, J.K.; Ghebremichael, K.A.; Amy, G.L. Application of the Purified Moringa Oleifera Coagulant for Surface Water Treatment; United Nations Educational, Scientific and Cultural Organization, Institute of water Education (UNESCO-IHE): Delft, The Netherlands, 2008; Volume 5.

4. Kansal, S.K.; Kumari, A. Potential of M. oleifera for the treatment of water and wastewater. Chem. Rev. 2014, 114, 4993-5010. [CrossRef]

5. Crini, G.; Lichtfouse, E. Advantages and disadvantages of techniques used for wastewater treatment. Environ. Chem. Lett. 2019, 17, 145-155. [CrossRef]

6. Xiong, B.; Piechowicz, B.; Wang, Z.; Marinaro, R.; Clement, E.; Carlin, T.; Uliana, A.; Kumar, M.; Velegol, S.B. Moringa oleifera f-sand Filters for Sustainable Water Purification. Environ. Sci. Technol. Lett. 2018, 5, $38-42$. [CrossRef]

7. Tripathi, A.; Mishra, A.K. Knowledge and passive adaptation to climate change: An example from Indian farmers. Clim. Risk Manag. 2017, 16, 195-207. [CrossRef]

8. Valverde, K.C.; Coldebella, P.F.; Silva, M.F.; Nishi, L.; Bongiovani, M.C.; Bergamasco, R. Moringa oleifera Lam. and Its Potential Association with Aluminium Sulphate in the Process of Coagulation/Flocculation and Sedimentation of Surface Water. Int. J. Chem. Eng. 2018, 2018, 12-15. [CrossRef]

9. Nwoba, E.G.; Vadiveloo, A.; Ogbonna, C.N.; Ubi, B.E.; Ogbonna, J.C.; Moheimani, N.R. Algal Cultivation for Treating Wastewater in African Developing Countries: A Review. Clean Soil Air Water 2020, 48, 1-14. [CrossRef]

10. Hoa, N.T.; Hue, C.T. Enhanced water treatment by Moringa oleifera seeds extract as the bio-coagulant: Role of the extraction method. J. Water Supply Res. Technol. 2018, 67, 634-647. [CrossRef]

11. Shirani, Z.; Santhosh, C.; Iqbal, J.; Bhatnagar, A. Waste Moringa oleifera seed pods as green sorbent for efficient removal of toxic aquatic pollutants. J. Environ. Manag. 2018, 227, 95-106. [CrossRef]

12. Rocha, V.V.F.; dos Santos, I.F.S.; Silva, A.M.L.; Sant'Anna, D.O.; Junho, A.L.; Barros, R.M. Clarification of high-turbidity waters: A comparison of Moringa oleifera and virgin and recovered aluminum sulfate-based coagulants. Environ. Dev. Sustain. 2019, 1-12. [CrossRef]

13. Adelodun, B.; Odedishemi, F.; Segun, M.; Choi, K.-S. Dosage and settling time course optimization of Moringa oleifera in municipal wastewater treatment using response surface methodology. Desalin. Water Treat. 2019, 167, 45-56. [CrossRef] 
14. Bello, O.S.; Lasisi, B.M.; Adigun, O.J.; Ephraim, V. Scavenging Rhodamine B dye using moringa oleifera seed pod. Chem. Speciat. Bioavailab. 2017, 29, 120-134. [CrossRef]

15. Camacho, F.P.; Sousa, V.S.; Bergamasco, R.; Ribau Teixeira, M. The use of Moringa oleifera as a natural coagulant in surface water treatment. Chem. Eng. J. 2017, 313, 226-237. [CrossRef]

16. Villaseñor-Basulto, D.L.; Astudillo-Sánchez, P.D.; del Real-Olvera, J.; Bandala, E.R. Wastewater treatment using Moringa oleifera Lam seeds: A review. J. Water Process Eng. 2018, 23, 151-164. [CrossRef]

17. Ndabigengesere, A.; Narasiah, K.S.; Talbot, B.G. Active agents and mechanism of coagulation of turbid waters using Moringa oleifera. Water Res. 1995, 29, 703-710. [CrossRef]

18. Muyibi, S.A.; Evison, L.M. Optimizing physical parameters affecting coagulation of turbid water with Morninga oleifera seeds. Water Res. 1995, 29, 2689-2695. [CrossRef]

19. Okuda, T.; Baes, A.U.; Nishijima, W.; Okada, M. Coagulation mechanism of salt solution-extracted active component in Moringa oleifera seeds. Water Res. 2001, 35, 830-834. [CrossRef]

20. Viotti, P.V.; Moreira, W.M.; dos Santos, O.A.A.; Bergamasco, R.; Vieira, A.M.S.; Vieira, M.F. Diclofenac removal from water by adsorption on Moringa oleifera pods and activated carbon: Mechanism, kinetic and equilibrium study. J. Clean. Prod. 2019, 219, 809-817. [CrossRef]

21. Natarajan, R.; Manivasagan, R. Effect of operating parameters on dye wastewater treatment using Prosopis cineraria and kinetic modeling. Environ. Eng. Res. 2019, 25, 788-793. [CrossRef]

22. Farzadkia, M.; Ehrampush, M.H.; Mehrizi, E.A.; Sadeghi, S.; Talebi, P.; Salehi, A.; Kermani, M. Investigating the efficiency and kinetic coefficients of nutrient removal in the subsurface artificial wetland of Yazd wastewater treatment plant. Environ. Health Eng. Manag. 2015, 2, 23-30.

23. Adelodun, B.; Ajibade, F.O.; Abdulkadir, T.S.; Bakare, H.O.; Choi, K.S. SWOT analysis of agro-waste based adsorbents for persistent dye pollutants removal from wastewaters. In Environmental Degradation: Causes and Remediation Strategies; Kumar, V., Singh, J., Kumar, P., Eds.; Agro Environ Media-Agriculture and Ennvironmental Science Academy: Haridwar, India, 2020; pp. 88-103.

24. Delelegn, A.; Sahile, S.; Husen, A. Water purification and antibacterial efficacy of Moringa oleifera Lam. Agric. Food Secur. 2018, 7, 1-10. [CrossRef]

25. Muyibi, S.A.; Noor, M.J.M.M.; Leong, T.K.; Loon, L.H. Effects of oil extraction from Moringa oleifera seeds on coagulation of turbid water. Int. J. Environ. Stud. 2002, 59, 243-254. [CrossRef]

26. Rice, E.W.; Baird, R.B.; Eaton, A.D.; Clesceri, L.S. APHA Standard Methods for the Examination of Water and Wastewater, 22nd ed.; APHA, AWWA, WEF: Washington, DC, USA, 2012. [CrossRef]

27. El Shahawy, A.; Heikal, G. Organic pollutants removal from oily wastewater using clean technology economically, friendly biosorbent (Phragmites australis). Ecol. Eng. 2018, 122, 207-218. [CrossRef]

28. Kumar, V.; Singh, J.; Kumar, P.; Kumar, P. Response surface methodology based electro-kinetic modeling of biological and chemical oxygen demand removal from sugar mill effluent by water hyacinth (Eichhornia crassipes) in a Continuous Stirred Tank Reactor (CSTR). Environ. Technol. Innov. 2019, 14, 100327. [CrossRef]

29. Báez, L.C.; Castro Rosas, J.; Villagómez Ibarra, J.R.; Palma Quiroz, I.; Páez Lerma, J.B.; Gómez Aldapa, C.A. Production of benzyl carbonyl (rose aroma) from whey and its effect on pollutant load removal. Environ. Dev. Sustain. 2019, 21, 609-619. [CrossRef]

30. United States Environmental Protection Agency (USEPA). Guidelines for Water Reuse; United States Environmental Protection Agency: Washington, DC, USA, 2012.

31. NESREA. National Environmental Standards and Regulations Enforcement Agency (Establishment) Act; NESREA: Abuja, Nigeria, 2009; pp. 1-21.

32. Kayode, O.; Luethi, C.; Rene, E. Management Recommendations for Improving Decentralized Wastewater Treatment by the Food and Beverage Industries in Nigeria. Environments 2018, 5, 41. [CrossRef]

33. Kane, C.; Bâ, A.; Mahamat, S.A.M.; Ayessou, N.; Mbacké, M.K.; Mar Diop, C.G. Combination of alum and extracted Moringa oleifera bioactive molecules powder for municipal wastewater treatment. Int. J. Biol. Chem. Sci. 2016, 10, 1918-1929. [CrossRef]

34. Boulaadjoul, S.; Zemmouri, H.; Bendjama, Z.; Drouiche, N. A novel use of Moringa oleifera seed powder in enhancing the primary treatment of paper mill effluent. Chemosphere 2018, 206, 142-149. [CrossRef]

35. Dotto, J.; Fagundes-Klen, M.R.; Veit, M.T.; Palácio, S.M.; Bergamasco, R. Performance of different coagulants in the coagulation/flocculation process of textile wastewater. J. Clean. Prod. 2019, 208, 656-665. [CrossRef] 
36. Al-gheethi, A.A.; Mohamed, R.M.S.R.; Wurochekke, A.A.; Nurulainee, N.R.; Mas Rahayu, J.; Amir Hashim, M.K. Efficiency of Moringa oleifera Seeds for Treatment of Laundry Wastewater. MATEC Web Conf. 2017, 103, 1-8. [CrossRef]

37. Rosmawanie, M.; Mohamed, R.; Al-Gheethi, A.; Pahazri, F.; Amir-Hashim, M.K.; Nur-Shaylinda, M.Z. Sequestering of pollutants from public market wastewater using Moringa oleifera and Cicer arietinum flocculants. J. Environ. Chem. Eng. 2018, 6, 2417-2428. [CrossRef]

38. Gao, Q.; Xu, J.; Bu, X.H. Recent advances about metal-organic frameworks in the removal of pollutants from wastewater. Coord. Chem. Rev. 2019, 378, 17-31. [CrossRef]

39. Samal, K.; Dash, R.R.; Bhunia, P. Effect of hydraulic loading rate and pollutants degradation kinetics in two stage hybrid macrophyte assisted vermifiltration system. Biochem. Eng. J. 2018, 132, 47-59. [CrossRef]

40. Dai, Y.D.; Shah, K.J.; Huang, C.P.; Kim, H.; Chiang, P.C. Adsorption of nonylphenol to multi-walled carbon nanotubes: Kinetics and isotherm study. Appl. Sci. 2018, 8, 2295. [CrossRef]

41. Sacher, F.; Gerstner, P.; Merklinger, M.; Thoma, A.; Kinani, A.; Roumiguières, A.; Bouchonnet, S.; Richard-Tanaka, B.; Layousse, S.; Ata, R.; et al. Determination of monochloramine dissipation kinetics in various surface water qualities under relevant environmental conditions-Consequences regarding environmental risk assessment. Sci. Total Environ. 2019, 685, 542-554. [CrossRef] [PubMed]

42. Chen, X.; Ren, P.; Li, T.; Trembly, J.P.; Liu, X. Zinc removal from model wastewater by electrocoagulation: Processing, kinetics and mechanism. Chem. Eng. J. 2018, 349, 358-367. [CrossRef]

43. Carvajal, A.; Akmirza, I.; Navia, D.; Pérez, R.; Muñoz, R.; Lebrero, R. Anoxic denitrification of BTEX: Biodegradation kinetics and pollutant interactions. J. Environ. Manag. 2018, 214, 125-136. [CrossRef]

44. Hernández-Martínez, R.; Valdivia-Rivera, S.; Betto-Sagahon, J.; Coreño-Alonso, A.; Tzintzun-Camacho, O.; Lizardi-Jiménez, M.A. Solubilization and removal of petroleum hydrocarbons by a native microbial biomass in a bubble column reactor. Rev. Mex. Ing. Quím. 2019, 18, 181-189. [CrossRef]

(C) 2020 by the authors. Licensee MDPI, Basel, Switzerland. This article is an open access article distributed under the terms and conditions of the Creative Commons Attribution (CC BY) license (http://creativecommons.org/licenses/by/4.0/). 